Studia nad Autorytaryzmem i Totalitaryzmem 43, nr 2 Wrocław 2021

https://doi.org/10.19195/2300-7249.43.2.9

MIKOŁAJ TARKOWSKI

ORCID: 0000-0003-1985-915X

Akademia Pomorska w Słupsku

mikolaj.tarkowski@apsl.edu.pl

\title{
Pomiędzy relacyjnością a ambiwalentnością. Rozwój idei własności i wolności w warunkach politycznych samodzierżawia rosyjskiego w XIX wieku jako lejtmotyw w twórczości naukowej Richarda Pipesa
} syjskie.

Słowa kluczowe: prawo własności, wolność, samodzierżawie (samowładztwo), Imperium Ro-

\author{
BETWEEN RELATIONALITY AND AMBIVALENCE: THE DEVELOPMENT \\ OF OWNERSHIP AND FREEDOM IN THE POLITICAL CONDITIONS OF \\ THE NINETEENTH-CENTURY RUSSIAN TSARIST AUTOCRACY AS A LEITMOTIV \\ OF RICHARD PIPES' SCIENTIFIC ACTIVITY
}

\begin{abstract}
The article illustrates that property rights, including in particular property and the relationship between property rights and the category of freedom in the nineteenth-century Russian Empire, was one of the most important areas of scientific activity of Richard Pipes. For centuries, both the institution of freedom and property were highly politicised. Based on Richard Pipes' findings, it can be concluded that the relationship between ownership and freedom manifested itself in the feature of relativity or ambivalence, depending on the time and individual parts of the Russian Empire. In the 19th century, the former mainly influenced the development of the monetary economy, while the latter strengthened the idea of samoderzhavyie in the political system. Richard Pipes noticed the sources of the antinomy between the idea of freedom and property in nineteenth-century Russia in the dynamically developing economic life and the "stillness" of the autocratic political power system. Following this concept, the article presents the doubts appearing among the St Petersburg ruling elite as well as provincial officials related to establishing the personal freedom of peasants in Russia, which finally took place in 1861. The system of tsarist autocracy in Russia, which was developing
\end{abstract}


throughout history, noticed significant links between property and freedom. A good example of this process was the confiscation of land property. In this regard, the article mentions political premises, the impact of the phenomenon of "paradox and tragedy," as well as the socio-economic calculations carried out in the field of confiscating private property in the western governorates of the Russian Empire, after the January Uprising of 1863.

Keywords: property rights, freedom, samoderzhavyie, tsarist autocracy, Russian Empire.

Richard Pipes to historyk, którego zainteresowania badawcze obejmowały wiele istotnych nurtów i zagadnień, fundamentalnych dla zrozumienia istoty samodzierżawia, kryzysu Imperium Rosyjskiego czy też podstaw ideowych i społecznych rewolucji bolszewickiej. Ten sam naukowiec, którego narracja historyczna bez wątpienia jest jedną z bardziej aktualnych w teraźniejszym dyskursie akademickim, kształtował przez ostatnie dziesięciolecia obraz sowietologii, w tym narodzin oraz erozji systemu komunistycznego w warunkach sowieckiego państwa totalitarnego, a także państw Trzeciego Świata. Jednocześnie przez współczesnych historyków jego twórczość definiowana jest jako niezależna oraz krytycznie odnosząca się do założeń tak zwanej postępowej szkoły sowietologii, akcentującej w procesach rozwoju historycznego Rosji i Europy Wschodniej elementy deterministyczne ${ }^{1}$.

$\mathrm{Na}$ kanwie wywiadu udzielonego w kwietniu 1991 roku przez Richarda Pipesa wspomniana doza krytycznego podejścia do tez zawartych w sowieckiej, ale i - co równie - istotne w części amerykańskiej historiografii, uwidoczniła się z całą mocą. Historyk, odpowiadając na pytanie, w jaki sposób ocenia dokonania naukowe sowietologii amerykańskiej, stwierdził:

używam względnie mało naszej, amerykańskiej literatury [...]. Nie znajdowałem w tych książkach wiele więcej niż w sowieckich. Nie ma w nich może tylu cytatów z Lenina, ale ujęcie jest takie samo: system carski był podły, nie dawał żadnej możliwości reform, sytuacja w Rosji na początku XX wieku była coraz bardziej krytyczna i kiedy nadeszła rewolucja [...], to znalazła naturalne oparcie w masach. To przecież sowieckie ujęcie. Jest to teza, której nie da się dowieść. Można dowieść czegoś wręcz przeciwnego. Masy wcale nie chciały rewolucji. To, co zrobili bolszewicy w listopadzie 1917 roku, to był spisek, konspiracja, a nie rewolucja ${ }^{2}$.

Autonomia naukowa inspirowała Pipesa także do konstruowania, na kanwie historii Rosji, kolejnych twórczych wniosków co do rozwoju własności prywatnej przy zastosowaniu różnorakich cezur temporalnych i geograficznych, obejmujących nie tylko koncepcje własności w monarchii angielskiej i rosyjskiej, ale też

1 W. Materski, Opinia dla Senatu Uniwersytetu Warszawskiego w zwiazku z nadaniem tytułu doktora honoris causa Profesorowi Richardowi Pipesowi, [w:] Historia est testis temporum. Księga pamiątkowa z okazji Jubileuszu Prsofesorów Richarda Pipesa, Piotra Wandycza, Zbigniewa Wójcika, red. J. Malicki, Warszawa 2017, s. 16.

2 Zacytowany fragment pochodzi z wywiadu udzielonego przez Richarda Pipesa w dniu 5 kwietnia 1991 roku Andrzejowi Nowakowi; zob.: „To imperium się rozpadnie”. Rozmowa $z$ Profesorem Richardem Pipesem, [w:] A. Nowak, O historii nie dla idiotów. Rozmowy i przypadki, Kraków 2019, s. 52-53. 
w niektórych współczesnych państwach zaliczanych do kręgu cywilizacji Zachodniej. Autor tych rozważań miał przy tym świadomość, iż jego ustalenia wywoływały kontrowersje. Miał na myśli przede wszystkim te koncepcje, które udowadniały, że „nowoczesne państwa dobrobytu” przewidują w swych strukturach i systemach prawnych rozwój czynników ,antywłasnościowych”. Tym samym ich polityka może być definiowana jako antyliberalna, co dotychczas było powszechnie uznawane za wyłączną cechę państw „,przednowoczesnych” czy też absolutystycznych ${ }^{3}$.

Interakcje powstające na styku prawa własności i kategorii wolności, biorąc pod uwagę wypowiedzi samego Pipesa, należy uznać za istotny motyw w twórczości naukowej tego wpływowego historyka. Badacz ten, doszukując się różnic w rozwoju historycznym Rosji i Zachodu, od lat pięćdziesiątych XX wieku prowadził badania naukowe, będąc jednocześnie przekonany, że kwestia własności prywatnej to jeden z kluczowych czynników kulturowej, ustrojowej, a także psychospołecznej ${ }^{4}$ dyferencjacji tych dwóch obszarów. Podkreślał zarazem, że

problem ten jest raczej słabo obecny w literaturze zachodniej, dlatego że traktuje się tutaj własność prywatną jako coś danego, coś oczywistego. Gdy jednak dochodzi się do Wschodu, do Rosji czy społeczeństw Azji, można dopiero przekonać się, jak fundamentalne znaczenie ma własność prywatna. Tego właśnie zdecydowanie brakowało w Rosji i to doprowadziło mnie do poglądu, że w Rosji był także w ogóle inny rodzaj rządu, inny ustrój niż w Europie Zachodniej — patrymonialny ${ }^{5}$.

Wiktoria Śliwowska, odnotowując co prawda swój polemiczny stosunek do niektórych głoszonych przez Richarda Pipesa tez, zaakcentowała, że sprawa definiowania własności prywatnej i jej ograniczeń w historii Rosji weszła do głównego kręgu zagadnień rozpatrywanych przez amerykańskiego badacza ${ }^{6}$. Ponadto Pipes zaznaczał, że władza polityczna w Rosji utożsamiała kwestię suwerenności

3 R. Pipes, Żytem. Wspomnienia niezależnego, Warszawa 2004, s. 249.

${ }^{4}$ Richard Pipes szczególnie dużo uwagi poświęcił kwestii psychicznego nastawienia ludności chłopskiej oraz robotników do własności, upatrując w niej jedną z przyczyn upadku Związku Sowieckiego. Podkreślił przy tym, iż erozja systemu komunistycznego nastąpiła z powodu wadliwości dwóch założeń. Po pierwsze, komunizm nie odpowiadał na naturalne potrzeby ludzkiej psychiki, skłonnej do takich cech, jak: żądza posiadania, pazerność i egoizm. Po drugie, system komunistyczny był ułomny z powodu innej wewnętrznej sprzeczności, która w ujęciu marksistowskim zakładała, że ludzka natura, w tym psychika, jest „niekończenie uległa”. Na tej podstawie władze totalitarne, wprowadzając wszelkie możliwe formy nacisku, mogły jedynie w okresie przejściowym, ograniczonym kolejną zmianą pokoleniową, wychować człowieka sowieckiego, zmuszonego do stłumienia określonych naturalnych odruchów psychicznych. O psychospołecznych podstawach rozwoju bolszewizmu w latach dwudziestolecia międzywojennego pisali ekonomiści społeczni i sowietolodzy działający w Wilnie - Władysław Zawadzki i Stanisław Swianiewicz. Zob. R. Pipes, Komunizm, Warszawa 2008, s. 165; por. M. Moczulski, Prace sowietologiczne Stanisława Swianiewicza, [w:] Stanisław Swianiewicz: ekonomista, sowietolog, historyk idei, red. B. Gaziński, Olsztyn 2011, s. 34-35.

5 „, To imperium się rozpadnie”..., s. 48-49.

6 W. Śliwowska, Opinia dla Senatu Uniwersytetu Warszawskiego w zwiazku z nadaniem tytulu doktora honoris causa Profesorowi Richardowi Pipesowi, [w:] Historia est testis temporum..., s. 34 .

Studia nad Autorytaryzmem i Totalitaryzmem 43, nr 2, 2021

(C) for this edition by CNS 
i prawa własności, co pozwalało na jednoczesne umacnianie koncepcji rosyjskiego jedynowładztwa, które wspierało się na filarze patrymonialnego modelu państwa ${ }^{7}$.

Zainteresowanie Pipesa problemem własności indywidualnej ${ }^{8}$ w Rosji skłoniło naukowca do osadzania tej instytucji w szerokim kontekście badawczym, obejmującym nie tylko ekonomiczne, ale też polityczne obszary ${ }^{9}$. Narracja historyczna Pipesa, nawiązująca często do dominującego w XIX wieku nurtu stosowanego $\mathrm{w}$ praktyce przez petersburskie elity polityczne, zwłaszcza w okresie rządów Aleksandra I oraz Mikołaja I, akcentowała pogląd, zgodnie z którym wolność właściciela do korzystania z przysługujących mu uprawnień zderzała się koncepcją głoszącą, że tak jak nieruchomości należące do skarbu monarchii, tak nieruchomości prywatne mogły podlegać władzy politycznej cesarza oraz aparatu administracyjnego państwa $\mathrm{z}$ tego tytułu, iż były położone $\mathrm{w}$ granicach terytorialnych Imperium Rosyjskiego ${ }^{10}$.

Z kolei w mniejszym stopniu Pipes spoglądał na własność ze stricte prawnego punktu widzenia, podczas gdy w Imperium Rosyjskim w XIX wieku zaczęły się kształtować zręby systemu prawa rzeczowego, w którym prawo własności odgrywało podstawową rolę i było definiowane w zasadzie dość nowocześnie, a także w sposób sprzyjający de iure rozwojowi gospodarki pieniężnej. W myśl norm płynących z przepisów Zbioru Praw Cesarstwa Rosyjskiego z 1832 roku oraz zgodnie z założeniami powstającej z wolna doktryny prawa cywilnego prawo własności było wyłącznym, nieograniczonym czasowo władztwem nad elementami majątku, które polegało na triadzie uprawień: posiadaniu, użytkowaniu i rozporządzaniu rzeczami, w tym rzeczami ruchomymi, jak również nieruchomościami ${ }^{11}$.

Jednocześnie trzeba zauważyć, że cesarz Mikołaj I, sygnując wejście w życie Zbioru Praw Cesarstwa Rosyjskiego, zaakceptował przepisy, które potwierdziły obowiązywanie uniwersalnego pojęcia własności w ujęciu abstrakcyjnym, a także dość nowoczesnym i stosunkowo liberalnym. W tym konkretnym przypadku

${ }^{7}$ M. Kornat, Sowiecki totalitaryzm w myśli historycznej Richarda Pipesa, „Studia z Dziejów Rosji i Europy Środkowo-Wschodniej” 53, 2018, z. 2, s. 19.

8 Richard Pipes, w kontrze do poglądów komunistycznych, w następujący sposób wyjaśniał ukształtowaną historycznie cechę własności prywatnej, jaką była trwałość i brak przejściowości tej idei: „Wszystkie dostępne dowody historyczne wskazują, że ziemia — główne źródło bogactwa od czasów przednowożytnych - jeżeli nie była własnością monarchów, zawsze należała do szczepów, klanów rodzinnych bądź indywidualnych jednostek [...]. Wynika z tego prosty wniosek, że własność prywatna nie jest w historii ludzkości zjawiskiem przejściowym, lecz stanowi stałą i trwałą cechę życia społecznego i jako taka jest niezniszczalna" — idem, Komunizm ..., s. 164-165.

9 M. Szczerbiński, Działalność badawcza i polityczna profesora Richarda Pipesa, [w:] Księga dedykowana Profesorowi Richardowi Pipesowi, red. M. Kocój, R. Małek, M. Szczerbiński, Gorzów Wielkopolski 2006, s. 10.

10 L. Słonimskij, O poziemielnoj sobstwiennosti iz toczki zrienija buduszczago grażdanskago ułożenija, Sankt Peterburg [1885], s. 12.

11 Swod zakonow Rossijskoj impierii. Powielenijem gosudara impieratora Nikołaja pierwago sostawlennyj, zakony grażdanskije, t. 10, cz. 1, Sankt Peterburg 1857, s. 73, 75 i 80 (art. 383-384, 393 i 420). 
należy zatem odnotować pewien wyłom wyłącznie na gruncie prawnym w generalnie kształtującej się w Rosji zasadzie patrymonialności, zgodnie z którą pojęcie władzy było zespolone $\mathrm{z}$ własnością. W konsekwencji założenie to wyklucza twierdzenie, że w zakresie ewolucji prawa własności „bolszewicki komunizm był dziedzicem Rosji carskiej"12.

Amerykański historyk na kartach swych książek, obejmujących zakresem temporalnym zarówno czasy dawnej Rusi, dominacji Moskwy, jak i okres imperialny w dziejach Rosji, w sugestywny sposób przedstawił proces genezy i kształtowania się idei upolityczniania prawa własności do prywatnych majątków ziemskich. Początków tego zjawiska społecznego należało doszukiwać się w silniejszej pozycji książąt z terenów północno-wschodnich aniżeli książąt wywodzących się z terenów wchodzących niegdyś w skład Rusi Kijowskiej. O tych pierwszych, którzy wykorzystując własny autorytet i mocną władzę polityczną, kolonizowali niezasiedlone dotychczas tereny, możemy mówić jako o władcach traktujących objęte ich imperium ziemie jako własność prywatną, a zamieszkującą je ludność jako najemników, pozbawionych praw osobistych oraz tytułów prawnych do nieruchomości ${ }^{13}$.

Wykonywanie władztwa nad rzeczą, połączone z uprawnieniem rozporządzania i dysponowania nią, w rosyjskiej tradycji prawnej miało wiele desygnatów. Nie stosowano bynajmniej od razu abstrakcyjnego terminu własność (sobstwiennost), który jako mający konotacje z nauką praw rzymskiego pojawił się w Rosji dopiero u schyłku XVIII wieku ${ }^{14}$, w dobie zasiadania na tronie rosyjskim pochodzącej z Niemiec Katarzyny $\mathrm{II}^{15}$. Początkowo własność prywatną - na terenach dawnej Rusi - nazywano wotczina, co oznaczało ,prawo do dziedziczenia po ojcu" i odpowiadało łacińskiemu patrimonium. To, co pozostawiał po śmierci ojciec, należało do jego następcy prawnego. Nie miało zrazem znaczenia, czy scheda po wstępnym miała postać rzeczy ruchomych, nieruchomości czy też rzeczy objętych władztwem politycznym, takich jak majątki ziemskie czy nieruchomości budujące w ogólnym ujęciu całe wsie, miasta czy też księstwa udzielne,

$12 \mathrm{~W}$ doktrynie i prawie sowieckim nie uwzględniono, w przeciwieństwie do Zbioru Prawa Cesarstwa Rosyjskiego z 1832 roku (Swod zakonow Rossijskoj Impierii..., t. 10), abstrakcyjnej definicji prawa własności, lecz na podstawie kodeksu cywilnego Rosyjskiej Federacyjnej Socjalistycznej Republiki Radzieckiej z 1922 roku własność dzielono zgodnie z kryterium podmiotowym na: państwową, spółdzielczą i prywatną (ograniczaną wyłącznie - w okresie NEP-u — do małych warsztatów pracy). Z kolei po likwidacji NEP-u pod koniec lat dwudziestych XX wieku zniesiono również własność prywatną. Natomiast w Konstytucji sowieckiej z 1936 roku pozostawiono tylko własność socjalistyczną oraz własność osobistą; zob. A. Lityński, Prawo Rosji i ZSRR 1917-1991: czyli historia wszechzwiąkowego komunistycznego prawa (bolszewików). Krótki kurs, Warszawa 2010, s. 220-221; por. M. Filipowicz, Emigranci i Jankesi. O amerykańskich historykach Rosji, Lublin 2007, s. 332-333.

13 R. Pipes, Rosja carów, Warszawa 1990, s. 41.

14 M. Władimirskij-Budanow, Obzor istorii ruskogo prawa, Moskwa 2005, s. 591.

15 R. Pipes, Rewolucja rosyjska, Warszawa 2006, s. 56. 
dziedziczone $\mathrm{w}$ drodze testamentowej, przy uwzględnieniu norm prawa zwyczajowego. Jednocześnie w Rosji nie zaistniała zasada primogenitury, wywodząca się na zachodzie Europy z okresu rządów Karola Wielkiego i obowiązywania systemu beneficjalnego. Tym samym nie obowiązywała reguła jednego dziedzica. Po śmierci kniazia każdy z następców otrzymywał zatem uprawniony udział, który stawał się jego patrymonium-wotcziną, podlegającą kolejnym podziałom testamentowym na wypadek śmierci.

Pipes podkreślał, że zgodnie z filozoficznymi teoriami Johna Locke'a, jak również ustaleniami rosyjskiego historyka Wasylego Kluczewskiego pierwsi właściciele średniowieczni w Rosji uzyskiwali silną pozycję polityczną poprzez wydzielenie przedmiotów ze stanu natury i zajmowanie — stanowiących res nullius - pierwotnych nieużytków ${ }^{16}$. Tym samym na pierwszych etapach rozwoju państwowości rosyjskiej, biorąc pod uwagę metafizyczne koncepcje prawa własności Immanuela Kanta, własność w stanie natury była co prawda nabywana, ale prowizorycznie. Biorąc pod uwagę słuszność tych założeń, musielibyśmy wykluczyć jednocześnie, że mieliśmy wówczas do czynienia ze stanem obywatelskości w Rosji, a tym samym z „rozumowymi podstawami” nabywania prawa własności. Jednocześnie warto przytoczyć, iż filozof z Królewca zdefiniował stan obywatelskości, który według niego był jedynym, w którym można nabyć własność peremptorycznie (stanowczo, ostatecznie). Kant twierdził:

Rozumowa podstawa nabycia może [...] spoczywać jedynie w idei zjednoczonej a priori [...] woli wszystkich, [...] którą zakłada się [...] milcząco jako nieodzowny warunek (conditio sine qua non); bowiem przez wolę jednostronną [księcia udzielnego - M.T.] nie można nałożyć na innych żadnego zobowiązania, którego oni sami przez się inaczej by nie posiadali. Jednakże stan, w którym wola wszystkich jest rzeczywiście zjednoczona w celu ustanawiania norm, jest stanem obywatelskim ${ }^{17}$.

Dziewiętnastowieczny historyk rosyjski Michaił Władimirskij-Budawnow, doprecyzowując ten istotny dla zrozumienia prawa własności element, pisał:

Pełne i nieograniczone władanie stanowi własność wówczas, gdy spotyka się z uznaniem ze strony innych osób i społeczeństwa: w ten sposób posiadanie staje się prawem, gdy nie ma osób oprotestowujących to prawo $^{18}$.

W okresie rozbicia dzielnicowego na Rusi, obok prywatnych dóbr ziemskich należących do książąt udzielnych, monasterów, a także tak zwanych czarnych ziem (uprawianych przez wolnych kmieciów), funkcjonowała własność ziemska należąca do właścicieli świeckich nazywanych bojarami. Uprawnienia własnościowe tej grupy koncentrowały się na otrzymywanych z woli księcia obszarach mających status wotczin, podlegających rozporządzaniu, w częściach równych w linii męskiej, w drodze testamentu, z zachowaniem praw córek dziedzica. W opinii Pipesa,

16 R. Pipes, Rosja carów..., s. 42-43.

17 I. Kant, Metafizyczne podstawy nauki prawa, Kęty 2006, s. 75.

18 M. Władimirskij-Budanow, op. cit., s. 591. 
nieco odmiennej od ustaleń Karola Koranyiego, wotcziny miały charakter alodialny. $\mathrm{Z}$ tego powodu ich posiadanie nie wiązało się z obowiązkiem pełnienia urzędu, a wyłącznie z realizacją życiowych i gospodarczych potrzeb osoby, która nimi dysponowała. Natomiast wotczinnicy ponosili obciążenia podatkowe, które były regulowane na rzecz skarbu książęcego. Niemniej z uwagi na nieukształtowanie się na Rusi stosunków lennych, typowych dla Europy Zachodniej, bojarzy nie podlegali obowiązkowi służenia jednemu księciu, mając jednocześnie uprawnienie do opuszczania miejsca i swobodnego przemieszczania się pomiędzy księstwami. W praktyce istniała nawet możliwość wypowiedzenia posłuszeństwa kniaziowi, lecz trudno doszukiwać się prawnych podstaw takiego uprawnienia. Niepodlegająca ewolucji, a przede wszystkim prawnemu usankcjonowaniu swoboda zaczęła być w okresie państwa moskiewskiego przekreślana przez zyskujących na znaczeniu politycznym wielkich książąt moskiewskich. W tym okresie wotczina przestała gwarantować posiadanie immunitetów oraz przywilejów ${ }^{19}$.

Podobnie sprawę uprawnień w zakresie prawa rzeczowego wotczinników przedstawił w połowie XIX wieku Iwan Engelman, który podkreślił, że pierwotnie, w okresie dawnej Rusi, władanie, które rozciągali właściciele świeccy nad nieruchomościami, choć miało walor pełności i nieograniczoności, było wyłącznie stanem faktycznym, bez prawnych gwarancji udzielanych ze strony państwa czy też przesłanek chroniących interes posiadacza ${ }^{20}$. Wraz z rozpoczęciem kształtowania się od końca XV wieku systemu jedynowładztwa ${ }^{21}$ możliwość migracji bojarów zmniejszyła się, a służba na ojcowiźnie stała się obowiązkiem wykonywanym wobec jednego pana. Jednocześnie zjawisku temu towarzyszyło ograniczenie praw do ojcowizny dla niektórych grup posiadaczy, w szczególności książąt ${ }^{22}$.

Z powodu nierozwijania stosunków lennych w Rosji ${ }^{23}$, początkowo pomijając specyficzną instytucję kormlenija, nie ukształtowała się na jej terenach forma własności w postaci lenna. Pierwsze wzmianki o rosyjskim wariancie własności lennej pochodzą z lat siedemdziesiątych XV wieku. Biorąc zatem pod uwagę chronologię rozwoju wydarzeń, pomiestja pojawiły się w Wielkim Księstwie Moskiewskim już po wystąpieniu procesu erozji uprawień wotczinników, co więcej — instytucja ta została wprowadzona jako oręż w walce $\mathrm{z}$ arystokracją, aby zniwelować pozycję polityczną zarówno książąt, jak i bojarów. Pipes uważał przy tym, że wbrew narracji wyrosłej z tradycji rewolucji francuskiej i prądów liberalnych

19 W opinii Karola Koranyiego wotcziny, których właściciel był zobowiązany do pełnienia służby wojskowej, nie stanowiły pełnej własności alodialnej. Zob. R. Pipes, Rosja carów..., s. 4752; por. K. Koranyi, Powszechna historia prawa, Warszawa 1976, s. 227.

20 I. Engelman, Priobrietienii prawa sobstwiennosti na ziemliu po russkomu prawu, Sankt Peterburg 1859, s. 44; zob. też M. Władimirskij-Budanow, op. cit., s. 591.

21 D. Szpoper, ,Kondycje mitawskie” i próba ograniczenia samodzierżawia w Imperium Rosyjskim na poczatku 1730 r., „Studia nad Autorytaryzmem i Totalitaryzmem” 39, 2017, nr 1, s. 163.

22 M. Władimirskij-Budanow, op. cit., s. 600.

23 J. Potulski, Rola i znaczenie tradycji w funkcjonowaniu współczesnych instytucji politycznych $w$ Rosji, Torun 2005, s. 98. 
ustrój feudalny w Europie Zachodniej, oparty na stosunkach lennych, stał się podstawą do tworzenia w niektórych państwach zrębów „nowoczesnego państwa” bazującego na zasadzie centralizacji władzy państwowej i jej suwerenności. Natomiast w Rosji — zdaniem tego samego badacza — kształtująca się przez wieki:

Mentalność patrymonialna położyła intelektualne i psychologiczne fundamenty pod autorytaryzm, cechujący większość rosyjskich władców, którego istotę można streścić następująco: „ziemi”, czyli patrymonium, odmawiano prawa do istnienia niezależnie od właściciela, czyli władcy i jego ,państwa"24.

Pomiestje, które od czasów Iwana III (1462-1505) coraz częściej były ustanawiane przez wielkich książą moskiewskich, były czasowa formą korzystania z dóbr ziemskich, która ustawała po zakończeniu służby wojskowej przez ich posiadacza, gdy dobra te wracały do księcia. Objęcie w użytkowanie dóbr pomiestnych nie uprawniało ich posiadacza do zbywania, dokonywania zastawu czy rozporządzania nimi na drodze spadkobrania testamentowego. To był główny czynnik odróżniający je od wotczin, które pozostawały w posiadaniu właścicieli niezależnie od tego, komu służyli.

Pomiestje otrzymywali głównie przedstawiciele grupy dworian ${ }^{25}$. W fazie kształtowania się opriczniny Iwan IV Groźny (1533-1584) przyznawał wypędzonej do Kazania szlachcie ziemie do czasowego użytkowania, co wiązało się z wcześniej przeprowadzonymi na wielką skalę wywłaszczeniami i konfiskatami majątków należących do szlachty. Za panowania tego samego władcy dokonał się również proces upodabniania statusu pomiestji i wotczin, gdyż zarówno pomieszczicy, jak i właściciele ziem w formie wotczin byli zobowiązani do pełnienia służby, jednakże bez zachowania dotychczasowego uprawnienia polegającego na możliwości zmiany księcia, któremu służyli. W 1556 roku Iwan IV wydał ukaz, zgodnie z którym przedstawicielom obu grup ustalono wymiar obciążeń, biorąc pod uwagę rodzaj zamieszkiwanego majątku ziemskiego oraz jego wielkość. W kolejnych latach ustanowiono normy prawne w formie ukazów, na mocy których osoby niewypełniające obowiązku zabezpieczenia określonej liczby zbrojnych sankcjonowano karami konfiskaty ziemi. Jednocześnie zachowały się świadectwa mówiące o przypadkach wywłaszczania (ekspropriacji) prawidłowo realizujących swe obowiązki wotczinników i konfiskowania należących od

${ }^{24}$ R. Pipes, Rosja carów..., s. 53-54; zob. też A. Pieczewski, Samodzierżawie a rozwój gospodarczy Królestwa Polskiego w ujęciu Jana Gottlieba Blocha, Warszawa 2019, s. 60 i 84 . Istotne ustalenia autora drugiej z wymienionych publikacj, należałoby uzupełnić o informację, iż terytorium Królestwa Polskiego (Carstwo Polskoje) nie pokrywało się z terytorium guberni zachodnich Cesarstwa Rosyjskiego, w skład których zasadniczo wchodziło sześć guberni północno-zachodnich (Siewiero-Zapadnyj kraj) i trzy południowo-zachodnie (Jugo-Zapadnyj kraj).

25 R. Pipes, Własność a wolność, Warszawa 2000, s. 263; zob. też M. Władimirskij-Budanow, op. cit., s. 659; A. Kijas, System pomiestny w Państwie Moskiewskim w XV-pierwszej połowie XVI wieku, Poznań 1984, s. 62. 
nich dóbr ziemskich. Zarówno pomieszcicy, jak i wotczinnicy nie dysponowali bowiem gwarancjami dla swych swobód i nie mogli oprzeć swego statusu osobistego na przywilejach, które nie były wydawane w tym zakresie do XVIII wieku. Generalnie prawo własności oraz związane z nim uprawnienie posiadania lub dysponowania dobrami ziemskimi wiązało się z określonymi powinnościami, nie zaś z wolnościami osobistymi przyznanymi przedstawicielom danej grupy ${ }^{26}$. W tym sensie nie może dziwić etymologia słowa $d$ worianin, która wiązała się z „bliskością w stosunku do monarchy” oraz ,ideą służby” na jego rzecz ${ }^{27}$.

Uzupełniając ten wątek, należy odnotować, iż instytucja konfiskaty dóbr ziemskich przeszła w Rosji ewolucję. W XIX wieku była ona utożsamiana przede wszystkim z rodzajem sankcji karnej ,zanurzonej” także w sferze obowiązywania norm prawa cywilnego. Zgodnie z normami Zbioru Praw Wojskowych (Swod wojennych postanowlenij) z 1859 roku konfiskatę skutkującą wygaśnięciem prawa własności do rzeczy ruchomych i nieruchomości organy państwowe mogły stosować wobec osób ,zamieszkujących gubernie przygraniczne”, w tym gubernie Kraju Zachodniego Cesarstwa Rosyjskiego, skazanych za przestępstwa o charakterze politycznym, obejmujące udział w ,buntach” i powstaniach ${ }^{28}$. Ponadto konfiskata na gruncie rosyjskiego prawodawstwa cywilnego była definiowana w myśl norm zawartych w tomie X Zbioru Praw Cesarstwa Rosyjskiego jako odebranie właścicielowi przez organy państwowe - w trybie nakazowym należącej do niego rzeczy w wyniku popełnienia przestępstwa polegającego na wznieceniu buntu lub spisku przeciwko państwu ${ }^{29}$. Po powstaniu styczniowym władze rządowe $\mathrm{w}$ guberniach zachodnich Imperium Rosyjskiego korzystały również z instytucji konfiskat, a także sekwestru. Generał-gubernator wileński Michaił Murawjow (1863-1865), dostrzegając relacyjność kategorii wolności i prawa własności do majątków ziemskich, które należały do szlachty polskiej, popierał procesy sekwestrowania nieruchomości należących do osób biorących udział w powstaniu. Jednocześnie uznawał, że odebranie faktycznego zarządu nad majątkami ziemskimi ich właścicielom naruszy interesy ekonomiczne szlachty, a tym samym pomniejszy ich wpływy polityczne ${ }^{30}$. Natomiast generał-gubernator kijowski Nikołaj Annienkow (1862-1865), zauważając tę samą relację, proponował, aby ją w pełni respektować, gdyż sytuowanie wolności i własności prywatnej na konfrontacyjnym kursie mogłoby się zakończyć zburzeniem ładu

26 R. Pipes, Własność a wolnośćc..., s. 263-268.

27 B. Uspienski, Religia i semiotyka, red. B. Żyłko, Gdańsk 2001, s. 104.

28 E. Waśkowski, Uczebnik grażdanskogo prawa. Wieszcznoje prawo, Sankt Peterburg 1896, s. $162-163$.

29 M. Tarkowski, Polacy na Litwie i Białorusi pod rządami Aleksandra II (1855-1881). Studium historyczno-prawne, Gdańsk 2018, s. 293.

30 M. Murawjow, List do A. Zielenoja, dat. Wilno 30 V 1863 r., [w:] H. Mościcki, Pod bertem carów, Warszawa 1924, s. 133. 
ekonomicznego Kraju Południowo-Zachodniego, a tym samym osłabieniem możliwości aprowizacyjnych wojsk rosyjskich ${ }^{31}$.

Wzmacniana przez stulecia koncepcja monarchii patrymonialnej w Rosji została wsparta przez zainicjowany w czasach dawnych Słowian przybywających do doliny Dniepru proces wschodniej ekspansji terytorialnej, rzutujący na imperialną politykę Cesarstw Rosyjskiego aż do XIX wieku. Według poglądów wspomnianego już Wasylego Kluczewskiego, na które powoływał się także amerykański historyk Henry Huttenbach, stale postępująca słowiańska migracja (słowiańska kolonizacja) była prapoczątkiem dla historii Rosji, a wszystkie inne zjawiska wynikały pośrednio bądź bezpośrednio z tego czynnika ${ }^{32}$. Natomiast zgodnie z ustaleniami jednego z uczniów profesora Richarda Pipesa, Witolda Rodkiewicza, w drugiej połowie XIX wieku w Kraju Północno-Zachodnim można odnotować istnienie specyficznego nurtu nawiązującego do zgoła odmiennej tendencji. $\mathrm{Z}$ powodów politycznych podjęto bowiem próbę wprowadzenia w życie koncepcji kolonizowania guberni zachodnich przez chłopów pochodzenia „rosyjskiego", którzy mieli zasiedlać te prowincje. Koncepcja opanowywania w ten sposób zachodnich okrain Imperium Rosyjskiego miała na celu podważenie pozycji społecznej i ekonomicznej szlachty polskiej. Działania zainicjowane w tym kierunku po powstaniu styczniowym przez Michaiła Murawjowa zostały jednak zawieszone kilka lat później jako mało skuteczne, choć reminiscencje polityki zasiedlania tych ziem włościanami pochodzącymi z guberni centralnych były obecne do końca lat osiemdziesiątych XIX wieku ${ }^{33}$.

Niezwykle istotnym wątkiem w twórczości naukowej Richarda Pipesa była także kwestia powiązania, mocno oddziałującej na poddanych i państwo, idei patrymonialności z brakiem rozwoju struktur parlamentarnych w Rosji do 1905 roku i swobód z nimi powiązanych. Pipes twierdził: „Ważną konsekwencją przywłaszczenia sobie całej ziemi przez carów oraz [...] możności konfiskaty wszelkich towarów będących w obrocie handlowym było to, że mogli oni nakładać podatki na ludność zgodnie z własną wolą". Autor dodawał też, że: „w Rosji [...] carowie nie potrzebowali niczyjej akceptacji przy nakładaniu lub podwyższaniu podatków, regaliów [...]. To zaś z kolei oznaczało, że parlamenty były im niepotrzebne"34.

Ponadto swoje prace badawcze Pipes poświęcił kwestii chłopskiej w Rosji, która była jednym z kluczowych czynników rozwoju nie tylko prawa własności

31 J. Legieć, K. Latawiec, Prawobrzeżna Ukraina. Czasy Annienkowa i Bezaka (1864-1868), [w:] Depolonizacja ziem zabranych (1864-1914). Koncepcje - mechanizmy decyzyjne - realizacja, red. S. Wiech, t. 2, Kielce 2018, s. 39.

${ }^{32} \mathrm{H}$. Huttenbach, Russian Imperialism from Ivan the Great to the Revolution, New Brunswick-New Jersey 1974, s. 21.

33 W. Rodkiewicz, Russian national policy in the Western Provinces of the Empire (18631905), Lublin 1998, s. 121.

34 R. Pipes, Własność a wolność..., s. 269; zob. też A. Bosiacki, Samodzierżawie a konstytucjonalizm. Dylematy ksztattowania rosyjskiego konstytucjonalizmu w latach 1905-1917, „Studia nad Autorytaryzmem i Totalitaryzmem” 34, 2012, nr 1, s. 11. 
w ogóle, ale i gospodarki w Imperium Rosyjskim w XIX wieku. W Rosji nie rozwinęła się początkowo własność pełna do gruntów ornych oraz nieruchomości miejskich. Utrzymywała się natomiast własność podzielona ${ }^{35}$. Co za tym idzie włościanie w państwie moskiewskim, stanowiąc zdecydowaną większość ludności, nie dysponowali żadnymi uprawnieniami ani swobodami usankcjonowanymi prawnie. Rozwój pełnej własności prywatnej ograniczany był między innymi przez instytucję wspólnoty wiejskiej (obszcziny, miru) ${ }^{36}$. Chłopi, niedysponujący własnością prywatną, pozostający w stosunku pańszczyźnianym (barszczina) ${ }^{37}$ lub płacący czynsz $(o b r o k)^{38}$, do połowy XIX wieku zamieszkiwali dobra nieruchome kontrolowane przez wspólnoty wiejskie lub też należące do właścicieli ziemskich lub państwa. Dość wspomnieć, iż amerykański badacz, podkreślający umacnianie się do XVIII wieku stosunku poddańczego, zakładającego, iż chłop pańszczyźniany w Rosji był skazany na wolę swego pana feudalnego, zauważył jednocześnie, że „różnica między feudałami a właścicielami niewolników niemal się zatarła" 39 .

Poglądy Pipesa na temat obszcziny korespondują z tymi wyrażanymi w okresie dwudziestolecia międzywojennego w Polsce. Edward Pisarek, urzędnik państwowy, w latach trzydziestych XX wieku pisał:

Nie znaczy bynajmniej, by chłop rosyjski ze swą psychiką był zaprzeczeniem tezy [...], że największą namiętnością człowieka jest pasja posiadania. Ludność włościańska w Rosji stanowiła do $90 \%$ ogółu ludności, stąd też ustrój obszczynny hamował rozwój indywidualistyczny, który już od dawna cechował życie gospodarcze na zachodzie Europy ${ }^{40}$.

Do chwili wprowadzenia w życie w 1861 roku postanowień reformy chłopskiej w Imperium Rosyjskim na obie grupy chłopów, zamieszkujących zarówno dobra ziemskie, jak i nieruchomości należące do skarbu monarchii, rozciągano obowiązki wynikające z poddaństwa. Pipes podkreślał, że „abolicjonistyczne” prądy, które przypłynęły z Zachodu, głoszące konieczność stopniowego wyprowadzania chłopów z zależności poddańczej, pojawiły się w Rosji po 1800 roku. Cesarz Aleksander I, sankcjonując ,prawo o wolnych rolnikach” z 1803 roku, przełamał dotychczasową tendencję i dokonał znaczącego kroku w długoletnim

35 A. Paszkiewicz, op. cit., s. 81.

36 R. Pipes, Własność a wolność..., s. 269; zob. też P. Bobek, Pobieżny przegląd dziejów chłopa polskiego. Od początku epoki piastowskiej do upadku państwa polskiego, Warszawa 1932, s. 12.

37 D. Szpoper, Własność w poglądach i działalności polskiego środowiska zachowawczego na ziemiach bytego Wielkiego Księstwa Litewskiego w latach 1855-1914, „Czasopismo HistorycznoPrawne" 56, 2004, z. 2, s. 260.

38 D. Lieven, Russia's rulers under the old regime, New Haven-London 1989, s. 17.

39 Cyt. za: R. Pipes, Własność a wolność..., s. 275-278; zob. też Kiedy kres Kresów? Rozmowa z prof. D. Beauvois, [w:] Wiele twarzy Ukrainy, red. I. Chruślińska, P. Tyma, Lublin 2005, s. 273; D. Lieven, W pożogę. Imperium, wojna i koniec carskiej Rosji, Warszawa 2018, s. 92.

40 E. Pisarek, Od obszczyny do kotchozu. Z form pospólnego użytkowania ziemi na wschodzie Europy, red. M. Jaskólski et al., Kraków 2012, s. 13. 
procesie dochodzenia chłopów do wolności osobistej, połączonego z rozwiązaniami prawnymi zakładającymi, iż uzyskanie wolności osobistej łączyło się z objęciem w posiadanie ziemi, $\mathrm{z}$ tym że za cenę wykupu ${ }^{41}$. Biorąc pod uwagę bogaty wachlarz poglądów na temat sprawy chłopskiej w dziewiętnastowiecznym Cesarstwie Rosyjskim, należy wspomnieć, że na kolejnych etapach rozwoju idei emancypacji chłopów pojawiały się także koncepcje wykluczające relacyjny związek między wolnością i własnością bądź posiadaniem czy też użytkowaniem gruntów przez włościan. W okresie rządów Mikołaja I rozpatrywana była bowiem koncepcja wyzwalania chłopów bez ziemi ${ }^{42}$. W kolejnych dekadach koncepcja braku relacyjności i wzajemnego uzupełniania się obu kategorii uległa jeszcze większemu zradykalizowaniu. Zdaniem Pipesa za taki stan rzeczy odpowiadała część inteligencji rosyjskiej, która — w swych poglądach „liberalna i radykalna” — sytuowała się bardziej „na lewo” od zachodnioeuropejskich elit intelektualnych, głosząc jednocześnie pod koniec XIX wieku „utopijne” i antywłasnościowe hasła, zgodnie z którymi każdy po likwidacji własności prywatnej miał użytkować duże nadziały gruntu ${ }^{43}$.

Z kolei petersburskie elity rządzace wykazywały potrzebe ochrony interesów majątkowych szlachty, która w dużej mierze korzystała $\mathrm{z}$ pracy włościan. Nie bez znaczenia były obowiązujące wówczas, a wywodzone z przepisów Karty szlacheckiej Katarzyny II z 1785 roku, normy stanowiące, że grunty użytkowane przez chłopów pańszczyźnianych należały do przedstawicieli szlachty. Od końca XVIII wieku przepisy potwierdzające prawo własności do ziemi korespondowały z kształtującym się z wolna korporacyjnym charakterem tej grupy społecznej. Ustrój mający taką właśnie cechę przewidywał możliwość powoływania instytucji samorządowych, jakimi były sejmiki szlacheckie, a także uprawnienie wybierania przedstawicieli szlachty do zarządu oraz sądów w guberniach i powiatach ${ }^{44}$. Szlachta rosyjska, zamieszkująca w zasadzie tak zwane gubernie wewnętrzne Imperium Rosyjskiego, zyskała na podstawie przepisów Karty instrumenty ochrony praw osobistych, przywilejów oraz prawa własności. Przyjęła zatem wejście w życie tych regulacji z nadzieją. Natomiast przedstawiciele szlachty litewskiej, posiadającej majątki ziemskie rozlokowane w prowincjach zachodnich Cesarstwa Rosyjskiego, wywodzący swoje uprawnienia ze źródeł ustanawianych w okresie istnienia Rzeczypospolitej Obojga Narodów, nie mogli odnotować zwiększenia, posiadanych wszak od wieków, uprawnień. Po wydarzeniach insurekcji

41 D. Szpoper, Kwestia chłopska w Cesarstwie Rosyjskim oraz w Królestwie Polskim w dobie panowania Aleksandra I, [w:] System polityczny, prawo i Konstytucja Królestwa Polskiego 1815-1830. W przededniu dwusetnej rocznicy powstania unii polsko-rosyjskiej, red. L. Mażewski, Radzymin 2013, s. 37.

42 R. Pipes, Własność a wolność..., s. 301-302.

43 R. Pipes, Rewolucja rosyjska. Trzy pytania, Warszawa 2007, s. 38-39.

44 R. Pipes, Własność a wolność..., s. 303; zob. też I. Poraj-Koszic, Oczerki istorii russkago dworianstwa ot połowiny IX do końca XVIII wieka: 862-1796, Sankt Peterburg 1874, s. 183. 
listopadowej 1830 roku i polityce rządowej wdrażanej przez generał-gubernatorów w Kijowie i Wilnie wystąpił wręcz regres uprawnień zagwarantowanych dotychczas przedstawicielom drobnej szlachty. W konsekwencji wejścia w życie ukazu z dnia 19 października 1831 roku szlachta nieposiadająca ziemi lub mająca problemy z udowodnieniem przynależności do stanu uprzywilejowanego została objęta kilkudekadowym procesem degradacji społecznej poprzez zaliczenie członków tej grupy do kategorii jednodworców, którzy zostali uznani za stan opodatkowany ${ }^{45}$. Przykładem rodziny szlacheckiej napotykającej w XIX wieku trudności $\mathrm{w}$ procedurze wylegitymowania szlachectwa byli Zahorscy, pochodzący z guberni wileńskiej ${ }^{46}$. Istotną kwestią pozostaje zarazem sprawa - podnoszona przez ziemiaństwo polskie - niemożności przypisywania uprawnień i wolności osobistych szlachcie bezrolnej, również zaliczonej do kategorii jednodworców, z uwagi na niski status społeczny i ekonomiczny przedstawicieli tej grupy, potwierdzony faktem dysponowania przez nich wyłącznie skrawkiem własnoręcznie uprawianej ziemi ${ }^{47}$.

Troska o stan ekonomiczny i status społeczny ziemiaństwa wiązała się z osiągnieciem celu nadrzędnego, jakim było zachowanie stabilnej pozycji politycznej cesarza i jego samodzierżawnych rządów, tradycyjnie opierającego swe imperium na przedstawicielach tej grupy. Jednakże sprawa włościańska, która łączyła się ze statusem prawnym szlachty, rozwijała się w dalszym ciągu. W pierwszej połowie XIX wieku można było odnotować przykłady instytucjonalizowania się kwestii chłopskiej w Imperium, które w ewolucyjnym procesie doprowadziły do oswobodzenia włościan, przekształcając ich w grupę wolnych pracowników rolnych. Pipes wskazał przy tym na powstałe w 1837 roku, sprawujące opiekę nad chłopami państwowymi gospodarującymi na ziemiach będących własnością skarbu monarchii, Ministerstwo Dóbr Państwowych (Ministerstwo Gosudarstwiennych Imusz$(c z e s t w)^{48}$. Historyk podkreślił przy tym istnienie czynnika, który stanowił jeden

45 E. Thaden, Russia's western borderlands, 1710-1870, Princeton 1984, s. 24 i 123; zob. też J. Sikorska-Kulesza, Deklasacja drobnej szlachty na Litwie i Białorusi w XIX wieku, Warszawa 1995, s. 26; M. Rolf, Rzady imperialne w Kraju Nadwiślańskim. Królestwo polskie i cesarstwo rosyjskie (1864-1915), Warszawa 2016, s. 46; D. Offord, V. Rjeoutski, G. Argent, The French language in Russia. A social, political, cultural and literary history, Amsterdam 2018, s. 106.

46 J. Sikorska-Kulesza, Wstęp, [w:] W. Zahorski, Moje wspomnienia, red. J. Sikorska-Kulesza, t. 1, Warszawa 2018, s. 12.

47 D. Beauvois, Walka o ziemię. Szlachta polska na Ukrainie prawobrzeżnej pomiędzy caratem a ludem ukraińskim 1863-1914, Sejny 1996, s. 131.

48 R. Pipes, Własność a wolność..., s. 300-301. O Ministerstwie Dóbr Państwowych oraz pierwszym ministrze hrabim Pawle Kisieljowie zob. zwłaszcza Wysoczajsze utwierżdiennoje uczrieżdienije ministerstwa gosudarstwiennych imuszczestw, 26 XII 1837, Polnoje Sobranije Zakonow Rossijskoj Imperii, t. 12, cz. 2, Sankt Peterburg 1838, s. 1039; zob. też A. Zabłocki-Diesjatowski, Graf P.D. Kisieljow i jego wriemja. Matieriaty dlia istorii imperatorow Aleksandra I, Nikołaja I i Aleksandra II, t. 2, Sankt Peterburg 1882; Istoriczeskoje obzorienije piatidiesiatilietniej diejatielnosti Ministerstwa Gosudarstwiennych Imuszczestw 1837-1887. Uczriezdienije i prieobrazowanija ministerstwa, cz. 1, Sankt Peterburg 1888. 
z głównych elementów dyskusji poświęconej emancypacji chłopów w Imperium Rosyjskim. W połowie XIX wieku, a zatem przed wprowadzeniem reformy włościańskiej, chłopi państwowi uzyskali uprawnienie umożliwiające im podejmowanie skutecznych czynności cywilnoprawnych obejmujących zawarcie umowy czy też nabywanie rzeczy na własność ${ }^{49}$. Tym samym w Imperium Rosyjskim z wolna dokonywał się proces aktywizacji ludności chłopskiej, skutkujący na gruncie prawnym wyposażeniem ich w cząstkę zdolności do czynności prawnych ${ }^{50}$.

Co równie ważne, wprowadzenie reformy chłopskiej w życie nie oznaczało automatycznego zastosowania mechanizmu uwłaszczenia chłopów. Pipes, wyjaśniając tę kwestę na przykładzie statusu prawnego chłopów państwowych, pisał: „ziemie wspólnotowe, które uprawiali chłopi [...] nie należały do nich aż do roku 1886, kiedy ich czynsz został zamieniony na raty zakupu"51. Natomiast włościanie zamieszkujący ziemie należące do szlachty litewskiej, na mocy manifestu Aleksandra II z 19 lutego 1861 roku oraz sankcjonowanej przez cesarza w tym samym dniu Miejscowej ustawy o terytorialnym urządzeniu włościan osiadłych na obywatelskich ziemiach w guberniach: wileńskiej, grodzieńskiej, kowieńskiej, mińskiej i części witebskiej, uzyskali intertemporalny status czasowo-zobowiązanych, uprawniajacy ich w przyszłości do uzyskania pełnej wolności osobistej. Ambiwalentność tych rozwiązań prawnych skutkowała na tym, że po dwóch latach włościanie zamieszkujący gubernie litewsko-białoruskie, z uwagi na występujący stan sprzeczności między ustawą miejscową a ukazami inwentaryzacyjnymi z lat czterdziestych XIX wieku, mogli - li tylko de iure - wykupić użytkowane dotychczas nadziały ziemi. Ustawa miejscowa nie likwidowała bowiem dawnych rozwiązań prawnych, a zatem przepisy ustawodawstwa włościańskiego z 1861 roku nakazywały przekazywanie chłopom nadziałów ziemi, które dotychczas użytkowali, bez uwzględnienia gruntów, które szlachta uzyskała od włościan na mocy wcześniej sporządzonych inwentarzy. Ta antynomia w praktyce była jednym z czynników prawnych blokujących możliwość poprawy statusu ludności chłopskiej w Kraju Zachodnim ${ }^{52}$.

$\mathrm{Na}$ status prawny chłopa w Cesarstwie Rosyjskim wpłynęły także inne czynniki i rozwiązania prawne wprowadzone mocą reformy z 1861 roku. Z jednej strony włościanie zyskali wolność osobistą, ich zdolność do podejmowania czynności prawnych otrzymała oparcie w prawodawstwie, a tym samym relacja między wolnością osobistą a możliwością wpływania na sytuację majątkową się

49 R. Pipes, Własność a wolność..., s. 301.

50 W. Kleandrowa, Gosudarstwo i prawo Rossij w pieriod utwierżdienija i razwitiia kapitalizma (wtoraja połowina XIX w.), [w:] Istorija Gosudarstwa i prawa Rossij, red. J. Titow, Moskwa 2006, s. 192.

51 R. Pipes, Wtasność a wolność..., s. 301.

52 D. Szpoper, Pomiędzy caratem a snem o Rzeczypospolitej. Myśl polityczna i działalność konserwatystów polskich w guberniach zachodnich Cesarstwa Rosyjskiego w latach 1855-1862, Gdańsk 2003, s. 225; zob. też W. Anisimow, Nadiety, [w:] Wielikaja rieforma 19 fiewralia 1861-1911. Russkoje obszczestwo i kriestianskij wopros w proszłom i nastojaszczem, red. A. Dżiwieliegow, S. Mielgunow, W. Piczeta, t. 6, Moskwa 1911, s. 88. 
umocniła. Z drugiej zaś strony chłopi w zakresie posiadanych swobód zostali ograniczeni przez instytucję wspólnoty wiejskiej. Przyczyna tkwiła w szczegółowych przepisach, zgodnie z którymi dotychczas użytkowane nadziały ziemi zostały przekazane na własność poszczególnym wspólnotom mającym odtąd osobowość prawną, a nie konkretnym gospodarzom. Tej koncepcji sprzyjali słowianofile. $Z$ kolei ich oponenci uważali, że ziemia powinna była przejść na własność użytkowników gruntów z chwilą spełnienia przez nich dotychczasowych zobowiązań. Inni uznali, że nadziały ziemi należało sprzedać uzyskującym wolność osobistą chłopom. Istnienie wielości koncepcji dowodziło, że na łonie petersburskich elit politycznych nie ukształtował się jednoznaczny pogląd, który opowiadałby się za ścisłym powiązaniem (relacyjnością) prawa własności do nieruchomości z przyznanymi de iure swobodami prawnymi ${ }^{53}$.

Koniec XIX wieku i rozwój różnych gałęzi przemysłu, infrastruktury kolejowej i banków kredytowych w Rosji przyczynił się do napłynięcia, na niespotykaną dotąd w tym państwie skalę, kapitału prywatnego, pochodzącego głównie z Francji ${ }^{54}$. W drugiej połowie tego samego stulecia, co w przypadku rozwoju gospodarki pieniężnej było naturalne, rozwinęła się doktryna prawa cywilnego $i$ handlowego dzięki działalności naukowej takich jej przedstawicieli, jak Gabriel Szerszeniewicz, będący jednym z twórców nowoczesnych poglądów poświęconych prawu handlowemu w Imperium Rosyjskim. Szerszeniewicz, analizując pod koniec XIX wieku przyczyny odmiennego rozwoju tej dziedziny prawa w Rosji i na zachodzie Europy, stwierdził, iż na ziemiach znajdujących się pod panowaniem rosyjskim nie mogło się w sposób intensywny rozwinąć prawo kupieckie. Przyczyn takiego zjawiska upatrywał w braku rozwoju klasycznych stosunków feudalnych oraz nieukształtowaniu się stanów społecznych, a także skutków za tym idących dla ziem znajdujących się w ciągu dziejów pod panowaniem rosyjskim. Szerszeniewicz pisał: „W Rosji nie było rozwarstwienia stanowego, a także walki pomiędzy stanami o swobody i przywileje” i dodawał: „Nie było ani potężnych i niezdobytych zamków, ukrywających w swoich wnętrzach samowolnych feudałów, ani silnych korporacji miejskich, chroniących mieszkańców miast przed ich arbitralnymi decyzjami”. Podane przez niego historyczne czynniki były nie tylko przyczyną braku rozwoju przywilejów stanowych, ograniczających władzę monarchy, lecz implikowały one, w przeciwieństwie do monarchii zachodnioeuropejskich, odmienny rozwój systemu prawa cywilnego. Szerszeniewicz miał w tym miejscu przede wszystkim na myśli kształtowanie się zasady jedności prawa cywilnego w Imperium Rosyjskim, która nie przewidywała, odwrotnie niż niektóre ustroje prawa prywatnego państw zachodnioeuropejskich, wyodrębnienia się prawa handlowego z sytemu prawa cywilnego ${ }^{55}$.

53 R. Pipes, Wtasność a wolność..., s. 305.

54 Ibidem, s. 307.

55 G. Szerszeniewicz, Kurs torgowogo prawa, cz. 1, Kazań 1892, s. 38. 
Zarówno w przypadku prawa własności do nieruchomości, jak i w kwestii ochrony kapitału władze rządowe przestrzegały ustanawianych norm prawnych ${ }^{56}$. Wszystkie instrumenty chroniące na gruncie prawa cywilnego prawo własności nie oddziaływały jednak wystarczająco skutecznie na działalność systemu politycznego o charakterze jedynowładczym. Obowiązywanie w Cesarstwie Rosyjskim na mocy Zbioru Praw Cesarstwa Rosyjskiego prawa rzeczowego, w tym prawa własności, a także całego pakietu prawodawstwa włościańskiego z 1861 roku i reformy agrarnej Piotra Stołypina z 1906 roku $^{57}$, wnoszących do zasadniczo „nieliberalnego reżimu” 58 prowolnościowy pierwiastek w dziedzinie stosunków społeczno-gospodarczych, nie zmieniło faktu, że każda osoba fizyczna, również właściciele ziemscy czy też posiadacze-użytkownicy nadziałów gruntowych, mogli zostać aresztowani i pozbawieni swobód osobistych, a także wydaleni z miejsca zamieszkania w procedurze zesłania administracyjnego ${ }^{59}$ za popełnienie przestępstw politycznych ${ }^{60}$.

Tę ambiwalentną, a zarazem kluczową dla stosunków społecznych w XIX wieku w Rosji postawę władz politycznych dostrzegł Pipes, który scharakteryzował ją na gruncie rozwoju idei słowianofilskiej następującymi słowami: „Słowianofile [...] rozwinęli teorię polityczną w pewnym sensie nowatorską. Jako pierwsi [...] myśleli w kategoriach równowagi pomiędzy państwem a społeczeństwem — wlast'i ziemla $[\ldots .$. ]". Historyk, rozwijając tę myśl, dodał:

słowianofile wprowadzili do rosyjskiego konserwatyzmu nowy element, a mianowicie ideę, że państwo i społeczeństwo mają swoje własne, usankcjonowane sfery aktywności, które winny być wzajemnie respektowane. Aprobowali oni autokrację, ale autokrację ściśle ograniczoną w swych celach i niewkraczającą do prywatnego życia obywateli, jednocześnie uważali, że obywatele ze swej stronny, niejako w zamian, nie powinni mieszać się do polityki ${ }^{61}$.

Zarówno Richard Pipes ${ }^{62}$, jak i inni współcześni historycy i historycy idei uznali, iż słowianofile uzyskali dość znaczny wpływ na działania podejmowa-

${ }^{56}$ R. Pipes, Własność a wolność..., s. 310.

57 R. Pipes, Rosja, komunizm i świat. Wybór esejów, Kraków 2002, s. 15.

$58 \mathrm{~S}$. Williams, Liberal reform in an illiberal regime. The creation of private property in Russia, 1906-1915, Stanford 2006, s. 181.

59 O instytucji zesłania administracyjnego szerzej zob. E. Kaczyńska, Syberia: największe więzienie świata (1815-1914), Warszawa 1991, s. 33-35; K. Grzybowski, Historia państwa i prawa Polski. Od uwłaszczenia do odrodzenia, red. J. Bardach. S. Grodziski, M. Senkowska-Gluck, t. 4, Warszawa 1982, zob. też M. Tarkowski, Ewolucja zesłania administracyjnego w XIX wieku w Rosji $w$ świetle wybranych wspomnień osób podejrzewanych o popetnienie przestępstw politycznych, [w:] Administracja bezpieczeństwa publicznego. Stużba więzienna w systemie bezpieczeństwa publicznego, red. M. Darabasz, Elbląg 2019, s. 36.

60 R. Pipes, Własność a wolność..., s. 310.

61 R. Pipes, Rosyjski konserwatyzm i jego krytycy. Studium kultury politycznej, Kraków 2009, s. 126.

62 R. Pipes, Krótka historia rewolucji rosyjskiej, Warszawa 2007, s. 8; zob. też idem, Piotr Struwe. Liberat na lewicy 1870-1905, Warszawa 2016, s. 44. 
ne przez Aleksandra II, wprowadzającego w drugiej połowie XIX wieku w Rosji reformy stanowiące rodzaj politycznej odwilży. Zdaniem wielu z nich ruch słowianofilski, jak również idee konserwatywne po upadku powstania styczniowego zaczęły ewoluować w kierunku ,etnonacjonalizmu i politycznego panslawizmu”. Koncepcje panslawistyczne, coraz bardziej zyskujące na popularności ${ }^{63}$, głoszone między innymi przez Mikołaja Danilewskiego, zakładały, że Słowianie stanowią pewien ,historyczny typ". W konsekwencji wszelkie idee głoszące swobody jednostki, ochronę kapitału prywatnego, kumulowania i zabezpieczania go przy wykorzystaniu instrumentów prawnych przewidzianych na gruncie prawa prywatnego, w tym cywilnego i handlowego, mogły być realizowane w praktyce, o ile nie podważały one wspomnianej wartości ${ }^{64}$.

Stworzenie ram prawnych do rozwoju gospodarki pieniężnej, powoływanie banków kredytowo-ziemskich i rozwój doktryny prawa cywilnego pogłębiały występujący przez cały XIX wiek rozdźwięk między systemem społeczno-gospodarczym a ustrojem politycznym genetycznie związanym z ideą patrymonialnej monarchii. Pipes występującą jednocześnie w Rosji relacyjność i ambiwalentność kategorii własności i wolności utożsamiał z ujawniającymi się w historii tego państwa, zwłaszcza w ostatnim stuleciu jego istnienia, „paradoksem i tragedią”. Charakteryzując powiększające się z czasem antynomie, pisał, iż

polegały one na tym, że kiedy rząd trwał przy anachronicznej koncepcji absolutyzmu, kraj przeżywał szybki rozwój gospodarczy, społeczny i intelektualny, który wymagał nowych, bardziej elastycznych form władzy administracyjnej. W wieku XIX rewolucja przemysłowa i stosunki kapitalistyczne przenikały do Rosji, pobudzając rozwój jednych, dawniej słabych warstw społecznych [...], a podkopując pozycję innych (na przykład ziemiaństwa) ${ }^{65}$.

Przy innej okazji autor podkreślił istniejący w XIX stuleciu rozdźwięk między rozwijającym się szybko życiem gospodarczym w Imperium Rosyjskim a „bezruchem" jego systemu politycznego ${ }^{66}$. Współcześni badacze idei samodzierżawia, obserwując rozwój tej koncepcji w XIX wieku, odrzucając podobnie jak Richard Pipes przesłanki determinizmu ekonomicznego, podkreślają, biorąc pod uwagę czynniki etyczne i kulturowe, że: „Pewnym paradoksem jest, że reżim własności prywatnej nie wpływał zasadniczo na pozycję ustrojową cara"67.

Potrzebę relacyjności między kategorią wolności a własnością zauważał w latach młodości Piotr Struwe (1870-1944), którego postawy światopoglądowe, społeczne i polityczne Richard Pipes scharakteryzował w odrębnej monografii. Historyk ten, analizując jeden z życiowych ideałów Struwego — liberalizm, pisał:

${ }^{63}$ H. Głębocki, Kresy Imperium. Szkice i materiaty do dziejów polityki Rosji wobec jej peryferii (XVIII-XXI wiek), Kraków 2006, s. 141.

64 A. Walicki, O inteligencji, liberalizmach i o Rosji, Kraków 2007, s. 281-282.

65 R. Pipes, Czerwone imperium. Powstanie Zwiazku Sowieckiego, Warszawa 2015, s. 8.

66 R. Pipes, Zamachowcy i zdrajcy. Z dziejów terroru w carskiej Rosji, Warszawa 2011, s. 17.

67 K. Chojnicka, Samodzierżawie, „Studia nad Autorytaryzmem i Totalitaryzmem” 39, 2017, nr 1, s. 158. 
Zasadniczym celem porządku politycznego i społecznego jest zatem stworzenie warunków optymalnie sprzyjających nieskrępowanej aktywności „kulturalnej”, czy to wyrażającej się w twórczości artystycznej, czy też w przedsiębiorczości gospodarczej. Ze względu na to [Piotr Struwe - M.T.] zawsze popierał prawo i prawa oraz własność prywatną $[\ldots]^{68}$.

Poglądy Struwego trafiły w Rosji na podatny grunt kształtujący się co najmniej od XVIII wieku, w początkach którego można odnaleźć, zgodnie z interpretacjami Krystyny Chojnickiej, wyrazy „ducha wolności i modelu jednostki - self made mana", kładącego podwaliny pod powstanie koncepcji potrzeby utworzenia klasy średniej ${ }^{69}$.

Podsumowując, rozwój idei własności w Imperium Rosyjskim, a także poszukiwania jej związków z kategorią wolności osobistej oraz z przywilejami politycznymi poddanych objętych imperium władców rosyjskich można uznać za jeden z kluczowych obszarów badawczych w twórczości Richarda Pipesa. Nurt ten, mimo że wymagał wyjaśniania wielu szczegółowych aspektów, a co za tym idzie prowadzenia badań mających wręcz cechy analiz anatomicznych, w twórczości amerykańskiego historyka jest wyraźnie obecny, a jego odziaływanie wydaje się długotrwałe. Pozwala on jednocześnie współczesnemu odbiorcy tez ulokowanych w książkach autorstwa Pipesa w sposób bardzo szczegółowy wniknąć w przyczyny erozji systemu jedynowładztwa w Imperium Rosyjskim, a także lepiej zrozumieć genezę wydarzeń i procesów występujących w zupełnie innej epoce, związanej z politycznym zwycięstwem idei rewolucyjnej i przejęciem władzy przez bolszewików.

\section{Bibliografia}

\section{Akty prawne}

Swod zakonow Rossijskoj impierii. Powielenijem gosudara impieratora Nikołaja pierwago sostawlennyj, zakony grażdanskije, t. 10, cz. 1, Sankt Peterburg 1857.

Wysoczajsze utwierżdiennoje uczrieżdienije ministerstwa gosudarstwiennych imuszczestw, 26 XII 1837, Polnoje Sobranije Zakonow Rossijskoj Imperii, t. 12, cz. 2, Sankt Peterburg 1838.

\section{Opracowania}

Beauvois D., Walka o ziemię. Szlachta polska na Ukrainie prawobrzeżnej pomiędzy caratem a ludem ukrainskim 1863-1914, Sejny 1996.

Bobek P., Pobieżny przeglad dziejów chłopa polskiego. Od początku epoki piastowskiej do upadku państwa polskiego, Warszawa 1932.

Bosiacki A., Samodzierżawie a konstytucjonalizm. Dylematy kształtowania rosyjskiego konstytucjonalizmu w latach 1905-1917, „Studia nad Autorytaryzmem i Totalitaryzmem” 34, 2012, nr 1.

68 R. Pipes, Piotr Struwe. Liberat na prawicy 1905-1944, Warszawa 2016, s. 383.

69 K. Chojnicka, Rosjanin Łomonosow jako zjawisko polityczne, Warszawa 2020, s. 36. 
Chojnicka K., Rosjanin Łomonosow jako zjawisko polityczne, Warszawa 2020.

Chojnicka K., Samodzierżawie, „Studia nad Autorytaryzmem i Totalitaryzmem” 39, 2017, nr 1.

Engelman I., Priobrietienii prawa sobstwiennosti na ziemliu po russkomu prawu, Sankt Peterburg 1859.

Filipowicz M., Emigranci i Jankesi. O amerykańskich historykach Rosji, Lublin 2007.

Głębocki H., Kresy Imperium. Szkice i materiały do dziejów polityki Rosji wobec jej peryferii (XVIII-XXI wiek), Kraków 2006.

Grzybowski K., Historia państwa i prawa Polski. Od uwłaszczenia do odrodzenia, red. J. Bardach. S. Grodziski, M. Senkowska-Gluck, t. 4, Warszawa 1982.

Huttenbach H., Russian Imperialism from Ivan the Great to the Revolution, New Brunswick-New Jersey 1974.

Istoriczeskoje obzorienije piatidiesiatilietniej diejatielnosti Ministerstwa Gosudarstwiennych Imuszczestw 1837-1887. Uczrieżdienije i prieobrazowanija ministerstwa, cz. 1, Sankt Peterburg 1888.

Kaczyńska E., Syberia: największe więzienie świata (1815-1914), Warszawa 1991.

Kant I., Metafizyczne podstawy nauki prawa, Kęty 2006.

Kiedy kres Kresów? Rozmowa z prof. D. Beauvois, [w:] Wiele twarzy Ukrainy, red. I. Chruślińska, P. Tyma, Lublin 2005.

Kijas A., System pomiestny w Państwie Moskiewskim w XV-pierwszej połowie XVI wieku, Poznań 1984.

Kleandrowa W., Gosudarstwo i prawo Rossij w pieriod utwierżdienija i razwitiia kapitalizma (wtoraja połowina XIX w.), [w:] Istorija Gosudarstwa i prawa Rossij, red. J. Titow, Moskwa 2006.

Koranyi K., Powszechna historia prawa, Warszawa 1976.

Kornat M., Sowiecki totalitaryzm w myśli historycznej Richarda Pipesa, „Studia z Dziejów Rosji i Europy Środkowo-Wschodniej” 53, 2018, z. 2.

Legieć J., Latawiec K., Prawobrzeżna Ukraina. Czasy Annienkowa i Bezaka (1864-1868), [w:] Depolonizacja ziem zabranych (1864-1914). Koncepcje - mechanizmy decyzyjne - realizacja, red. S. Wiech, t. 2, Kielce 2018.

Lieven D., Russia's rulers under the old regime, New Haven-London 1989.

Lieven D., W pożogę. Imperium, wojna i koniec carskiej Rosji, Warszawa 2018.

Lityński A., Prawo Rosji i ZSRR 1917-1991: czyli historia wszechzwiąkowego komunistycznego prawa (bolszewików). Krótki kurs, Warszawa 2010.

Materski W., Opinia dla Senatu Uniwersytetu Warszawskiego w zwiazku z nadaniem tytułu doktora honoris causa Profesorowi Richardowi Pipesowi, [w:] Historia est testis temporum. Ksiega pamiątkowa z okazji Jubileuszu Profesorów Richarda Pipesa, Piotra Wandycza, Zbigniewa Wójcika, red. J. Malicki, Warszawa 2017.

Moczulski M., Prace sowietologiczne Stanisława Swianiewicza, [w:] Stanisław Swianiewicz: ekonomista, sowietolog, historyk idei, red. B. Gaziński, Olsztyn 2011.

Mościcki H., Pod berłem carów, Warszawa 1924.

Nowak A., O historii nie dla idiotów. Rozmowy i przypadki, Kraków 2019.

Offord D., Rjeoutski V., Argent G., The French language in Russia. A social, political, cultural and literary history, Amsterdam 2018.

Pieczewski A., Samodzierżawie a rozwój gospodarczy Królestwa Polskiego w ujęciu Jana Gottlieba Blocha, Warszawa 2019.

Pipes R., Czerwone imperium. Powstanie Zwiazku Sowieckiego, Warszaw 2015.

Pipes R., Komunizm, Warszawa 2008.

Pipes R., Krótka historia rewolucji rosyjskiej, Warszawa 2007.

Pipes R., Piotr Struwe. Liberat na lewicy 1870-1905, Warszawa 2016.

Pipes R., Piotr Struwe. Liberat na prawicy 1905-1944, Warszawa 2016.

Pipes R., Rewolucja rosyjska, Warszawa 2006.

Pipes R., Rewolucja rosyjska. Trzy pytania, Warszawa 2007.

Pipes R., Rosja carów, Warszawa 1990.

Studia nad Autorytaryzmem i Totalitaryzmem 43, nr 2, 2021

(C) for this edition by CNS 
Pipes R., Rosja, komunizm i świat. Wybór esejów, Kraków 2002.

Pipes R., Rosyjski konserwatyzm i jego krytycy. Studium kultury politycznej, Kraków 2009.

Pipes R., Wtasność a wolność, Warszawa 2000.

Pipes R., Zamachowcy i zdrajcy. Z dziejów terroru w carskiej Rosji, Warszawa 2011.

Pipes R., Żyłem. Wspomnienia niezależnego, Warszawa 2004.

Pisarek E., Od obszczyny do kotchozu. Z form pospólnego użytkowania ziemi na wschodzie Euro$p y$, red. M. Jaskólski, J. Kloczkowski, M. Kuniński, R. Legutko, J. Majchrowski, T. Merta, B. Szlachta, Kraków 2012.

Poraj-Koszic I., Oczerki istorii russkago dworianstwa ot połowiny IX do końca XVIII wieka: 8621796, Sankt Peterburg 1874.

Potulski J., Rola i znaczenie tradycji w funkcjonowaniu współczesnych instytucji politycznych w Rosji, Toruń 2005.

Rodkiewicz W., Russian national policy in the Western Provinces of the Empire (1863-1905), Lublin 1998.

Rolf M., Rządy imperialne w Kraju Nadwiślańskim. Królestwo polskie i cesarstwo rosyjskie (18641915), Warszawa 2016.

Sikorska-Kulesza J., Deklasacja drobnej szlachty na Litwie i Białorusi w XIX wieku, Warszawa 1995.

Słonimskij L., O poziemielnoj sobstwiennosti iz toczki zrienija buduszczago grażdanskago ułożeni$j a$, Sankt Peterburg [1885].

Szczerbiński M., Działalność badawcza i polityczna profesora Richarda Pipesa, [w:] Księga dedykowana Profesorowi Richardowi Pipesowi, red. M. Kocój, R. Małek, M. Szczerbiński, Gorzów Wielkopolski 2006.

Szerszeniewicz G., Kurs torgowogo prawa, cz. 1, Kazań 1892.

Szpoper D., , Kondycje mitawskie” i próba ograniczenia samodzierżawia w Imperium Rosyjskim na poczatku 1730 r., „Studia nad Autorytaryzmem i Totalitaryzmem” 39, 2017, nr 1.

Szpoper D., Kwestia chtopska w Cesarstwie Rosyjskim oraz w Królestwie Polskim w dobie panowania Aleksandra I, [w:] System polityczny, prawo i Konstytucja Królestwa Polskiego 18151830. W przededniu dwusetnej rocznicy powstania unii polsko-rosyjskiej, red. L. Mażewski, Radzymin 2013.

Szpoper D., Pomiędzy caratem a snem o Rzeczypospolitej. Myśl polityczna i działalność konserwatystów polskich $w$ guberniach zachodnich Cesarstwa Rosyjskiego w latach 1855-1862, Gdańsk 2003.

Szpoper D., Własność w poglądach i działalności polskiego środowiska zachowawczego na ziemiach bytego Wielkiego Księstwa Litewskiego w latach 1855-1914, „Czasopismo Historyczno-Prawne" 56, 2004, z. 2.

Śliwowska W., Opinia dla Senatu Uniwersytetu Warszawskiego w zwiąku z nadaniem tytułu doktora honoris causa Profesorowi Richardowi Pipesowi, [w:] Historia est testis temporum. Ksiega pamiątkowa z okazji Jubileuszu Profesorów Richarda Pipesa, Piotra Wandycza, Zbigniewa Wójcika, red. J. Malicki, Warszawa 2017.

Tarkowski M., Ewolucja zesłania administracyjnego $w$ XIX wieku $w$ Rosji w świetle wybranych wspomnień osób podejrzewanych o popetnienie przestęstw politycznych, [w:] Administracja bezpieczeństwa publicznego. Stużba więzienna $w$ systemie bezpieczeństwa publicznego, red. M. Darabasz, Elbląg 2019.

Tarkowski M., Polacy na Litwie i Białorusi pod rzadami Aleksandra II (185--1881). Studium historyczno-prawne, Gdańsk 2018.

Thaden E., Russia's western borderlands, 1710-1870, Princeton 1984.

Uspienski B., Religia i semiotyka, red. B. Żyłko, Gdańsk 2001.

Walicki W., O inteligencji, liberalizmach i o Rosji, Kraków 2007.

Waśkowski E., Uczebnik grażdanskogo prawa. Wieszcznoje prawo, Sankt Peterburg 1896. 
Wielikaja rieforma 19 fiewralia 1861-1911. Russkoje obszczestwo i kriestianskij wopros w proszłom i nastojaszczem, red. A. Dżiwieliegow, S. Mielgunow, W. Piczeta, t. 6, Moskwa 1911.

Williams S., Liberal reform in an illiberal regime. The creation of private property in Russia, 19061915, Stanford 2006.

Władimirskij-Budanow W., Obzor istorii ruskogo prawa, Moskwa 2005.

Zabłocki-Diesjatowski A., Graf P.D. Kisieljow i jego wriemja. Matieriaty dlia istorii imperatorow Aleksandra I, Nikołaja I i Aleksandra II, t. 2, Sankt Peterburg 1882.

Zahorski W., Moje wspomnienia, red. J. Sikorska-Kulesza, t. 1, Warszawa 2018. 